\title{
Evaluation of the Influence of Some Abiotic Factors on the Microbiological Quality of Groundwater in Soa Sub-division, Cameroon, Africa
}

\author{
George Mafany ${ }^{a}$, Edith Brunelle Mouafo Tamnou ${ }^{b}$, \\ Armel Zacharie Ekoa Bessa ${ }^{\mathrm{c}^{*}}$, Joséphine Ndjama ${ }^{\mathrm{a}^{*}}$, \\ Gisèle Liliane Machuetum ${ }^{b}$, Frank Aristide Tchouape Noubouossie ${ }^{b}$ \\ ${ }^{a}$ Hydrological Research Center (HRC), Institute of Geological and Mining Research (IRGM), \\ P.O.Box 4110, Nlongkak-Yaoundé, Cameroon. \\ ${ }^{b}$ Laboratory of Hydrobiology and Environment, Faculty of Science, University of Yaoundé 1 , \\ P.O.Box 812, Yaoundé, Cameroon. \\ ${ }^{c}$ Department of Earth Sciences, University of Yaoundé 1, P.O.Box 812, Yaoundé I, Cameroon.
}

Authors' contributions

This work was carried out in collaboration among all authors. Authors EBMT, JN and AZEB designed the study, performed the statistical analysis, wrote the protocol and wrote the first draft of the manuscript. Authors GLM, GM and FATN managed the analyses of the study. Authors JN and MN managed the literature searches. All authors read and approved the final manuscript.

Article Information

DOI: 10.9734/ARRB/2021/v36i1230470 Editor(s):

(1) Dr. Paola Angelini, University of Perugia, Italy. Reviewers:

(1) Darapaneni Vivek, Anvek Institute of Biomolecular Research, India.

(2) Manu Mitra, University of Bridgeport, USA.

(3) Paul N. Goldwater, Adelaide University, Australia.

(4) C. V. Chittibabu, University of Madras, India. (5) Bukola Margaret Popoola, Ajayi Crowther University, Nigeria. Complete Peer review History, details of the editor(s), Reviewers and additional Reviewers are available here: https://www.sdiarticle5.com/review-history/80919

Original Research Article

Received 12 October 2021 Accepted 20 December 2021 Published 22 December 2021

\section{ABSTRACT}

Groundwater samples were collected during April and August 2016 from five hand-dug wells in Soa subdivision, Cameroon, Africa, with the aim to assess the microbiological quality of them and the health risk they (it) posed to the population in the study area. The low piezometric levels $(9-20 \mathrm{~m})$ and the little variation in curb-stone heights $(0.58-1.05 \mathrm{~m})$ suggest that the wells are vulnerable to 
pollution. The physicochemical parameters show that the groundwater of Soa is acidic and poorly mineralized. The residents (population that is) dominated by students are not connected to the supply of water, making them to take recourse to groundwater for potable and general domestic use. Bacteriological analysis of the water samples focused on the search and listing of heterotrophic mesophilic aerobic bacteria (HAMB). Also, bacteria of the Enterobacteriaceae family were isolated, identified and listed (Escherichia, Klebsiella, Shigella, Citrobacter, Providencia). The analyses were carried out through standard, selective and conventional gallery culture media, using surface spreading, streaking and sub-culturing techniques. Different ions were also measured for the physicochemical component according to the usual analytical techniques. The low values of oxidability recorded clearly indicated the organic pollution of the study area. The organic matter was found largely influencing the increase in bacterial load (which is high and varied). The presence of these germs degrades the quality of the water, which varies from one site to the other, with the important factors being the proximity of the sources of pollution to the well and its poor maintenance. As local populations are using these ground waters without any prior treatment, they are prone to health risks over the period time.

Keywords: Groundwater; pathogenic bacteria; enterobacteria; abiotic variable.

\section{INTRODUCTION}

In Africa and particularly in Cameroon, water supply companies are still facing major challenges in the provision of fresh potable water to the population. Access to safe drinking water therefore remains a key issue [1,2] in most developing countries. In Cameroon, the main public water supply company (CAMWATER) has not been able to match its supply with the rapidly increasing population in the country. As a result, many have resorted to the use of alternative sources with groundwater as the most preferred. Though the trend is gradually shifting towards the use of boreholes to harness the groundwater, most of the supply is largely through unprotected hand dug wells, making the source highly vulnerable to microbial pollution. Even though the boreholes relatively more protected than the hand-dug wells, their location is conditioned by the owner and whose decision to influence the location is also limited within the confines of his property. The result is that most boreholes are located within the contamination range $(<100 \mathrm{~m})$ of pit latrines and septic tanks. Users take the clear appearance of the groundwater to imply purity in complete oblivion of its microbial load $[3,4]$. Bacteria of various types make up the majority of the microflora in groundwater $[4,5]$. Looking for organisms that suggest contamination or fecal pollution is one way to determine the quality of the water. Enterobacteriaceae (total and fecal coliforms) is a useful indicator whose presence in nondisinfected groundwater depicts degradation of the water quality induced by surface water inputs. Its presence in water can be an indicator of the potential presence of human enteric viruses $[6,7]$.

Numerous studies have been carried out on the bacteriological quality of groundwater in in Yaoundé $[8,9,10,11]$. It is to be noted that the study area is located in the peri-urban outskirts of Yaoundé. The previous studies show that groundwater in Yaoundé harbors a varied microflora, made up of fecal bacteria and opportunistic pathogenic bacteria. Isolated bacteria of the Enterobacteriaceae family include Enterobacter, Escherichia, Klebsiella, Citrobacter, Serratia, Salmonella, Shigella, Edwarsiella, Proteus and Providencia genera. Their population dynamics is influenced by meteorological parameters and certain abiotic factors of the environment [12].

However, little is known about the groundwater quality of Soa, where pressure on groundwater is increasing rapidly as a result of increasing domestics use. This increase is driven by the inability of CAMWATER, the main public water supply company, to meet the needs of the Soa population. The population of the study area comprises mainly the student community of the university town of Soa, which is found resorting to alternative water source, viz., the groundwater, as the most favored source because of its presumed good quality. However, the groundwater susceptibility to contamination [1315] can only be gauzed through scientific study and data generation. The paucity of data on this important source of potable water for the Soa community leaves a knowledge gap on its quality and health effects. It is for this reason that the 
aim of this work is to (i) assess the bacteriological quality, (ii) determine the physicochemical composition and (iii) establish the morphometric and piezometric parameters of the sampling points in for groundwater in Soa.

\section{MATERIALS AND METHODS}

\subsection{Study Area}

Soa subdivision is located in the Mefou and Afamba Division in the Centre Region of Cameroon; some $14 \mathrm{~km}$ northeast of Yaoundé. It is roughly circumscribed by latitude $3^{\circ} 50^{\prime}$ to $4^{\circ} 10^{\prime}$ $\mathrm{N}$ and longitude $11^{\circ} 30^{\prime}$ to $11^{\circ} 40^{\prime} \mathrm{E}$ (Fig. 1). Altitudes range from 600 to $730 \mathrm{~m}$ and can drop to $300 \mathrm{~m}$ in the valleys. It has a surface area of $326 \mathrm{~km}^{2}$ [16]. The prevailing climate is humid equatorial. The vegetation consists of forest formations in the south which gradually passes to a peri-forest savannah towards the north [17]. Soa is found in the Nyong basin in which the hydrographic network that is revolves around the Afamba river and its main tributaries: Mbende and Foulou. The soils are mainly ferralitic with two main variants: red clayey and acidic ferralitic soils $(\mathrm{pH}<5.5)$ and yellow clayey iron-rich ferralitic soils $[18,19]$.

\subsection{Sampling and Analysis Methods}

Five groundwater samples were collected from five different wells in the study area. The samples were collected between April and August 2016 using protocol developed by the French Standardization Agency [AFNOR (NF-T 90-10)]. The samples were collected in 1liter polyethylene bottles. Prior to this, each bottle was washed and rinsed three times with the water to be sampled, then filled to the brim and sealed hermetically, before being carried in coolers to the laboratory. Samples for microbiological analysis were collected using 500 $\mathrm{mL}$ sterilized glass bottles. All samples were stored at $4{ }^{\circ} \mathrm{C}$ in coolers immediately after collection and during transportation to the Laboratory of Hydrobiology and Environment and Chemical Laboratory of the Institute of Agricultural Research for Development (IRAD) and then analyzed within 24 hours of sample collection. Table 1 summarizes the codes assigned to these wells, their geographical coordinate and their average altitudes. The coordinates and the elevation of the various wells were obtained on the field using a Garmin 60CSX GPS.

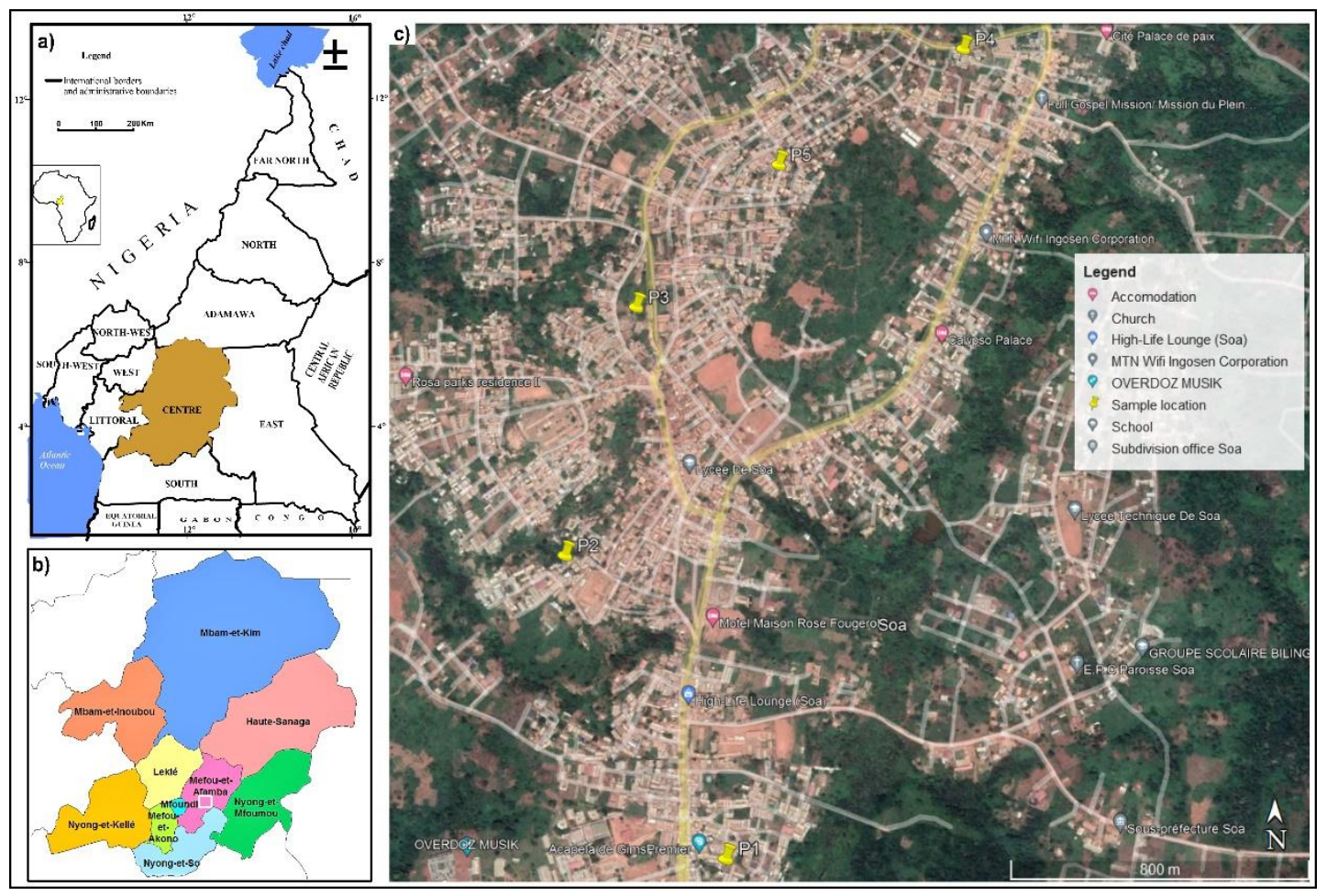

Fig. 1. Investigated area and sampling location: a) location map of the Region of the study area, b) location of Department of the study area and its surroundings, and c) location of sampling area and water points in the locality of Soa, Cameroon, Africa 
Table 1. GPS coordinates of the wells selected at Soa

\begin{tabular}{lllll}
\hline Wells & Sites & \multicolumn{3}{c}{ GPS coordinates } \\
\cline { 3 - 5 } & & Altitudes $(\mathbf{m})$ & Latitudes & Longitudes \\
\hline P1 & In front of the University & 663 & $03^{\circ} 57^{\prime} 57.3$ & $11^{\circ} 36^{\prime} 40.0$ \\
P2 & Behind the public primary school & 659 & $03^{\circ} 58^{\prime} 23.1$ & $11^{\circ} 35^{\prime} 26.2$ \\
P3 & Entered general high school & 684 & $03^{\circ} 58^{\prime} 45.2$ & $11^{\circ} 35^{\prime} 32.5$ \\
P4 & Police station & 684 & $03^{\circ} 59^{\prime} 09.6$ & $11^{\circ} 36^{\prime} 02.8$ \\
P5 & Château (Foe Road) & 700 & $03^{\circ} 58^{\prime} 58.4$ & $11^{\circ} 36^{\prime} 45.5$ \\
\hline
\end{tabular}

\subsubsection{Analysis of abiotic parameters}

On the field, the height of the curb-stone and the piezometric level were measured using a graduated rope. The temperature was measured using a B11403 mercury column thermometer graduated to $1 / 10$ th of a degree and the $\mathrm{pH}$ was measured using a $\mathrm{HACH} \mathrm{HQ} \mathrm{30d} \mathrm{Flexi} \mathrm{portable}$ multimeter. Physicochemical parameters were measured according to the recommendations of Rodier et al. [20]. The total dissolved solids (TDS) and electrical conductivity (EC) of the samples were measured using a TDS/EC portable HANNA series HT 8733 conductivity meter. The dissolved oxygen was determined using a WTW Oxy 340 brand oximeter. The values were given in percentage oxygen saturation.

The color of the water was obtained using a $\mathrm{HACH}$ DR/2000 spectrophotometer and the reading was taken at the wavelength of $455 \mathrm{~nm}$. The nitrogen forms in $\mathrm{mg} / \mathrm{L}$ (nitrate and ammoniacal nitrogen) were determined by colorimetry using a spectrophotometer $(\mathrm{HACH}$ $\mathrm{DR} / 2000$ ) and the Nessler reagents were used for the determination of ammoniacal nitrogen and nitraver IV for nitrates. Oxidability, alkalinity and dissolved carbon dioxide were determined by volumetric assay using the appropriate reagents. The major cations, magnesium $\left(\mathrm{Mg}^{2+}\right)$, calcium $\left(\mathrm{Ca}^{2+}\right)$, sodium $\left(\mathrm{Na}^{+}\right)$and potassium $\left(\mathrm{K}^{+}\right)$were determined by conductimetry using a cleonex ICS 90 and ICS 1100 liquid phase ion chromatograph and the results were expressed in $\mathrm{mg} / \mathrm{L}$.

\subsubsection{Bacteriological analysis}

Bacteriological analysis comprised the screening of heterotrophic mesophilic aerobic bacteria (HMAB) and Enterobacteriaceae besides the identification of strains of Enterobacteriaceae isolated from well water samples. These microorganisms were identified and enumerated by filtering homogeneous aliquots of $100 \mathrm{~mL}$ through a membrane with a pore diameter of $0.45 \mu \mathrm{m}$. The membranes were then placed on selective media for 24 hours at $37{ }^{\circ} \mathrm{C}$ in a thermostatic oven. The following media were used: Plate Count Agar (PCA) was used for the isolation of HMAB and Eosin Methylene Blue (EMB) lactose agar was used for the isolation of Enterobacteriaceae [21].

The identification of the bacterial colonies isolated on the EMB medium was carried out first by macroscopic observation of the colonies, including the shape, size, outline and color of the colonies. Subsequently, biochemical tests were carried out using the classical gallery [21]. The colony count was performed with the naked eye using a colony counter. The results were expressed in log (CFU / $100 \mathrm{~mL}$ ).

\subsubsection{Statistical analysis}

The correlation coefficients between bacterial densities and physicochemical variables were calculated using Spearman's " $r$ " correlation test. The comparisons of the mean of the bacterial densities were carried out by means of the $\mathrm{H}$ tests of Kruskal-Wallis and $U$ of Mann-Whitney. These tests were performed using SPSS 16.0 software.

\section{RESULTS AND DISCUSSION}

\subsection{Hydrological and Morphometric Parameters of Wells}

The hydrological parameters vary from one well to the other (Table 2). The piezometric levels vary between 9 and $20 \mathrm{~m}$ while the heights of the curb-stone range between 0.58 and $1.05 \mathrm{~m}$. The highest curb-stone height was recorded at well P3 and the lowest at well P2. The measured parameters (Table 2) indicate that wells $\mathrm{P} 1$ and $\mathrm{P} 2$ are not protected, while the wells $\mathrm{P} 3, \mathrm{P} 4$, and P5 are protected as the P1 well was not at all covered and the P2 well had a rusted and perforated metal cover. On the other hand, the wells P3, P4 and P5 were properly covered and relatively well secured (Table 2 ). 
Table 2. Morphometric and hydrological parameters of the wells studied

\begin{tabular}{llllll}
\hline Wells & P1 & P2 & P3 & P4 & P5 \\
\hline Piezometric level $(\mathrm{m})$ & 9 & 19.5 & 16 & 18 & 20 \\
Height of curb-stone $(\mathrm{m})$ & 0.9 & 0.58 & 1.05 & 0.85 & 0.80 \\
Well protection & absent & absent & present & present & present \\
\hline
\end{tabular}

\subsection{Physicochemical Parameters}

Table 3 shows the mean values and standard deviations of the physicochemical variables for each well. The temperature of the groundwater samples that ranges from $(22.80 \pm 0.2-23.60 \pm$ $0.4^{\circ} \mathrm{C}$ ) shows very little variation. This low thermal variation could be explained by the low conductivity of the soil. This is in agreement with the report of Asi and Ajeagah [22] in the same area $\left(23.5^{\circ} \mathrm{C}-24^{\circ} \mathrm{C}\right)$. The $\mathrm{pH}$, that ranges from 5.3 to 6.3 ascribes an acidic character to the groundwater of Soa. Hence, the well P1 is more acidic than the other four wells (P2, P3, P4 and $P 5)$. These results are similar to the groundwater of Yaoundé obtained by Moussina Yaka et al. [10]. The acidity of the groundwater is believed to be due to the acidic nature of the soils in the region [23]. It could also be linked to the production of $\mathrm{CO}_{2}$ in the surface layers of the soil under the action of biological activities [24, 25, 26]. In addition, the $\mathrm{pH}$ values obtained suggests a decrease in the dissolution of $\mathrm{CO}_{2}$ in the groundwater. This result is similar to that of the groundwater of Cross River Basin in Nigeria [27].

The mean values of EC and TDS varied depending on the water sampling points. They were high for the well P1 $(289.4 \mu \mathrm{S} / \mathrm{cm}$ and 145 $\mathrm{mg} / \mathrm{L}$ respectively) and relatively low for the other wells of P2 $(35.7 \mu \mathrm{S} / \mathrm{cm}$ and $17 \mathrm{mg} / \mathrm{L}), \mathrm{P} 3$ $(47 \mu \mathrm{S} / \mathrm{cm}$ and $23 \mathrm{mg} / \mathrm{L}), \mathrm{P} 4(33.2 \mu \mathrm{S} / \mathrm{cm}$ and $16.4 \mathrm{mg} / \mathrm{L})$ and P5 (47.5 $\mathrm{\mu S} / \mathrm{cm}$ and $24 \mathrm{mg} / \mathrm{L})$. The major cation $\left(\mathrm{Na}^{+}, \mathrm{K}^{+}, \mathrm{Mg}^{2+}\right.$ and $\mathrm{Ca}^{2+}$ and nitrate $\left(\leq 2.5 \mathrm{mg} / \mathrm{L}\right.$ of $\mathrm{NO}^{3-)}$ contents remain generally low. These values show that these waters are soft and lowly mineralized. However, the high values observed in well $\mathrm{P} 1(27.80 \mathrm{mg} / \mathrm{L}$ of $\mathrm{Na}^{+}, 4.97 \mathrm{mg} / \mathrm{L}$ of $\mathrm{K}^{+}, 1.10 \mathrm{mg} / \mathrm{L} \mathrm{of}^{2} \mathrm{Mg}^{2+}, 8.30$ $\mathrm{mg} / \mathrm{L}$ of $\mathrm{Ca}^{2+}$ and $1.60 \mathrm{mg} / \mathrm{L}$ of $\mathrm{NO}^{3-}$ ) for these different variables could be due to the low level of protection of the well (absence of well cover and presence of grasses along the internal wall of the well) and also to the shallow depth of the well. This is in conformity with the assertion that groundwater that is nearer to the surface of earth is more susceptible to pollution as noted by Mbawala et al. [28]. The mineralogical composition of the groundwater could also be influenced by the mineralogy of the host rock, the contact time with the minerals, the water circulation speed, the aquifer water renewal time and the rainfall [29].

The mean water color values fluctuated from 11.4 to $56.6 \mathrm{Pt}$. Co. This high color value was largely influenced by the drop in the water column in each well in July. The oxidability values ranged from 3.3 to $5.3 \mathrm{mg} / \mathrm{L}$. They showed that the water is moderately loaded with organic matter. The WHO sets a threshold of 5 $\mathrm{mg} / \mathrm{L}$ of oxidability in drinking water.

The oxygen saturation percentage (Sat \%) varied from $64.8 \%$ to $66.5 \%$ and reflected a fairly good oxygenation of the water. These results differed from those obtained by Nougang et al. [30], wherein a low to medium saturation rate in dissolved oxygen was recorded. The relatively high value $(66.50 \%)$ recorded at the P2 well may be attributed to the fact that the well is open. The latter aspect indeed increases the contact and exchange between water and air in the ambient environment.

The dissolved carbon dioxide contents fluctuated between 2.8 and $4.2 \mathrm{mg} / \mathrm{L}$. The $\mathrm{NO}^{3-}$ contents were relatively low for wells P2 $(0.4 \mathrm{mg} / \mathrm{L}), \mathrm{P} 3$ (0.8 mg /L), P4 (0.5 mg /L) and P5 (0.9 mg/L) as compared to well P1 $(1.6 \mathrm{mg} / \mathrm{L})$. However, they remain below the standards recommended by the WHO for the drinking water (50 mg /L).

\subsection{Bacteriological Parameters}

Qualitatively, whitish to yellowish colonies of various diameters were the obtained colors on PCA medium. Those obtained on EMB medium and identified did belong to 5 bacterial genera of the Enterobacteriaceae family (in all the water samples). These include the genera of Escherichia, Klebsiella, Shigella, Citrobacter and Providencia.

Quantitatively, the means of bacterial abundances shown in (Table 4) varied from one bacteria to another. The abundances of heterotrophic aerobic mesophilic bacteria (HAMB) ranged from 5.45 to 5.95 log CFU / $100 \mathrm{~mL}$ in different wells. These recorded 
abundances are above the WHO standard [31] which sets a threshold of $2 \log$ CFU / $100 \mathrm{~mL}$ and significantly higher $(P<0.05)$ than those of the identified genera of Enterobacteriaceae (Table 4).

Bacteriological analysis carried out on water samples taken from the wells during the study period show that, these waters contain bacteria resulting from fecal contamination. Among the main groups of bacteria indicating fecal contamination, two have been represented. These are total coliforms represented by bacteria of the genera Klebsiella and Citrobacter, and fecal coliforms represented mainly by the genera Escherichia. The abundances of these two groups of bacteria have varied from one well to another over time. The abundances of bacteria of the genus Klebsiella ranged from 3.15 to $3.76 \mathrm{log}$ CFU / $100 \mathrm{~mL}$ and those of the genera Citrobacter fluctuated from 3.45 to 4.03 log CFU / $100 \mathrm{~mL}$. The mean values of the Klebsiella and Citrobacter abundances recorded were 1.56 and $1.85 \log$ CFU / $100 \mathrm{~mL}$ respectively, while the abundances of Escherichia ranged from 0 to 3.08 log CFU / $100 \mathrm{~mL}$ (Table 4). These values were all higher than the standards set by the WHO for drinking water. These standards set the levels of fecal coliforms and total coliforms at 1.3 and 1.69 log CFU / $100 \mathrm{~mL}$ respectively. These results are similar to those obtained by Buguioh et al. [4] in the case of spring water of the West region of Cameroon.

Apart from these two bacterial groups, other pathogenic and opportunistic bacteria identified are bacteria of the genera Shigella and Providencia. The abundances of bacteria of the genera Shigella oscillated between 3.25 and 4.17log CFU / $100 \mathrm{~mL}$. Those of the genera Providencia fluctuated between 2.9 and $3.73 \mathrm{log}$ CFU / $100 \mathrm{~mL}$ (Table 4). The permanent presence of these pathogenic bacteria and their high abundance 3.79 log CFU / $100 \mathrm{~mL}$ (Shigella) reflects the degree of pollution in these water samples and the high health risk. Similar results have been obtained by Mpakam et al. [32] in Bafoussam and Moussina Yaka et al. [10], in Yaoundé, where many pathogens such as Escherichia coli, Salmonella, Shigella and many other bacteria witnessing fecal contamination have been observed in the ground waters.

Table 3. Average values and standard deviations of the physicochemical parameters measured by station

\begin{tabular}{llllll}
\hline Parameters & Well 1 & Well 2 & Well 3 & Well 4 & Well 5 \\
\hline $\mathrm{T}\left({ }^{\circ} \mathrm{C}\right)$ & $23.20 \pm 0.2$ & $22.80 \pm 0.2$ & $23.60 \pm 0.3$ & $23.10 \pm 0.3$ & $23.60 \pm 0.4$ \\
$\mathrm{pH}$ & $6.30 \pm 0.4$ & $5.60 \pm 0.3$ & $5.40 \pm 0.6$ & $5.30 \pm 0.4$ & $5.50 \pm 0.6$ \\
$\mathrm{TDS}(\mathrm{mg} / \mathrm{L})$ & $145 \pm 27.1$ & $17 \pm 4.4$ & $23 \pm 4.5$ & $16.40 \pm 6.1$ & $24 \pm 3.7$ \\
$\mathrm{EC}(\mu \mathrm{S} / \mathrm{cm})$ & $289.40 \pm 50.5$ & $35.70 \pm 9.5$ & $47 \pm 10.1$ & $33.20 \pm 13.8$ & $47.50 \pm 5.8$ \\
Color $(\mathrm{Pt} . \mathrm{Co})$ & $20.20 \pm 19.4$ & $56.60 \pm 59.3$ & $45.40 \pm 56.8$ & $11.40 \pm 16.8$ & $23 \pm 74$ \\
Alcalinity $(\mathrm{mg} / \mathrm{L})$ & $1.80 \pm 0.4$ & $1.80 \pm 0.4$ & $1.80 \pm 0.4$ & $1.80 \pm 0.4$ & $2.20 \pm 1$ \\
$\mathrm{CO}_{2}(\mathrm{mg} / \mathrm{L})$ & $4.20 \pm 1.5$ & $2.80 \pm 0.9$ & $2.80 \pm 1.5$ & $3.50 \pm 1.2$ & $2.80 \pm 0.9$ \\
$\mathrm{O}_{2}(\%)$ & $64.80 \pm 2.3$ & $66.50 \pm 6.1$ & $65.20 \pm 2.9$ & $65.40 \pm 3.7$ & $65.50 \pm 3.2$ \\
$\mathrm{Oxydability}^{2}(\mathrm{mg} / \mathrm{L})$ & $3.40 \pm 1.4$ & $3.30 \pm 2.3$ & $5.10 \pm 0.3$ & $4.80 \pm 1$ & $5.30 \pm 0.6$ \\
$\mathrm{NO}_{3}^{-}(\mathrm{mg} / \mathrm{L})$ & $1.60 \pm 0.4$ & $0.40 \pm 0.3$ & $0.80 \pm 0.5$ & $0.50 \pm 0.2$ & $0.90 \pm 0.7$ \\
$\mathrm{Mg}^{2+}(\mathrm{mg} / \mathrm{L})$ & $1.10 \pm 0.5$ & $0.40 \pm 0.1$ & $0.60 \pm 0.2$ & $0.50 \pm 0.3$ & $0.70 \pm 0.4$ \\
$\mathrm{Ca}^{2+}(\mathrm{mg} / \mathrm{L})$ & $8.30 \pm 4.5$ & $3.50 \pm 0.6$ & $4.80 \pm 2.2$ & $3.10 \pm 0.9$ & $5.30 \pm 2.5$ \\
$\mathrm{~K}^{+}(\mathrm{mg} / \mathrm{L})$ & $4.97 \pm 2.6$ & $0.93 \pm 0.2$ & $1.38 \pm 1.1$ & $1.12 \pm 0.8$ & $0.5 \pm 0.1$ \\
$\mathrm{Na}^{+}(\mathrm{mg} / \mathrm{L})$ & $27.80 \pm 16.9$ & $1.02 \pm 0.6$ & $1.83 \pm 1.6$ & $1.42 \pm 0.8$ & $2.05 \pm 2.4$ \\
\hline
\end{tabular}

Table 4. Averages of bacterial abundances according to wells

\begin{tabular}{lcllll}
\hline & \multicolumn{7}{c}{ Wells } \\
\hline Bacteria (Log UFC/ 100 ml) & P1 & P2 & P3 & P4 & P5 \\
\hline HAMB & 5.95 & 5.69 & 5.78 & 5.79 & 5.45 \\
Escherichia & 3.08 & 2.90 & 2.30 & 0 & 0 \\
Klebsiella & 3.45 & 3.38 & 3.15 & 3.76 & 3.34 \\
Shigella & 3.66 & 3.25 & 4.17 & 4.07 & 3.80 \\
Citrobacter & 3.60 & 3.88 & 3.45 & 3.5 & 4.03 \\
Providencia & 3.41 & 3.08 & 3.73 & 2.90 & 3.25 \\
\hline
\end{tabular}


The major differences in bacterial abundance observed in the five analyzed wells are influenced by the structural character (opened or closed) of the well. A greater bacterial density in closed wells (P3, P4 and P5) than in open wells (P1 and P2) was noted. This shows that closed wells are more polluted than open wells. In fact, the closed wells considered in this study, although protected on the outside by adequate copings, covers and pulley systems, contain other sources of pollution in their environment. These are most likely the toilets in the case of well P4 located upstream of sloping ground and about $2 \mathrm{~m}$ from the well. In addition, these wells as we observed are close to the agricultural fields and gardens. All these parameters account for the high abundance of the observed bacterial populations as well as their great diversity. Socioeconomic characteristics of households influences the type of toilet and the mode of waste management [33]. This implies that high income households will have better sanitary facilities and manage their wastes better. The low income status of most in the households of the study area explains the poor sanitary facilities and low waste management capabilities which are directly impinging on the quality of groundwater in the Soa.

\subsection{Relative Frequencies of Bacterial Abundance}

The ratios (monthly relative frequencies) of the average abundances of each bacterial genus identified to those of HAMB on one hand and to the average sum of Enterobacteriaceae identified on the other hand were calculated and are represented respectively in Figures 2 and 3 . Figure 2 shows that the abundances of the different identified genera vary from one month of sampling to the other, appearing high in some months and dropping to rarity in some other months. This is the case with bacteria of the genus Escherichia, which turned out to be very rare during the months of May, June, July and August. In addition, the abundances of the bacterial genera identified represent only $4 \%$ of the HAMB counted.

In all the bacteria identified, those of the genus Shigella showed the greatest abundance (Fig. 3). Eighty percent of the enterobacteria identified in June were of the genus Shigella while less than $20 \%$ was of the genera Escherichia and Providencia. Similar results have been obtained by Nanga et al. [12] in Yaoundé and Ndjama et al. [34] in Douala.

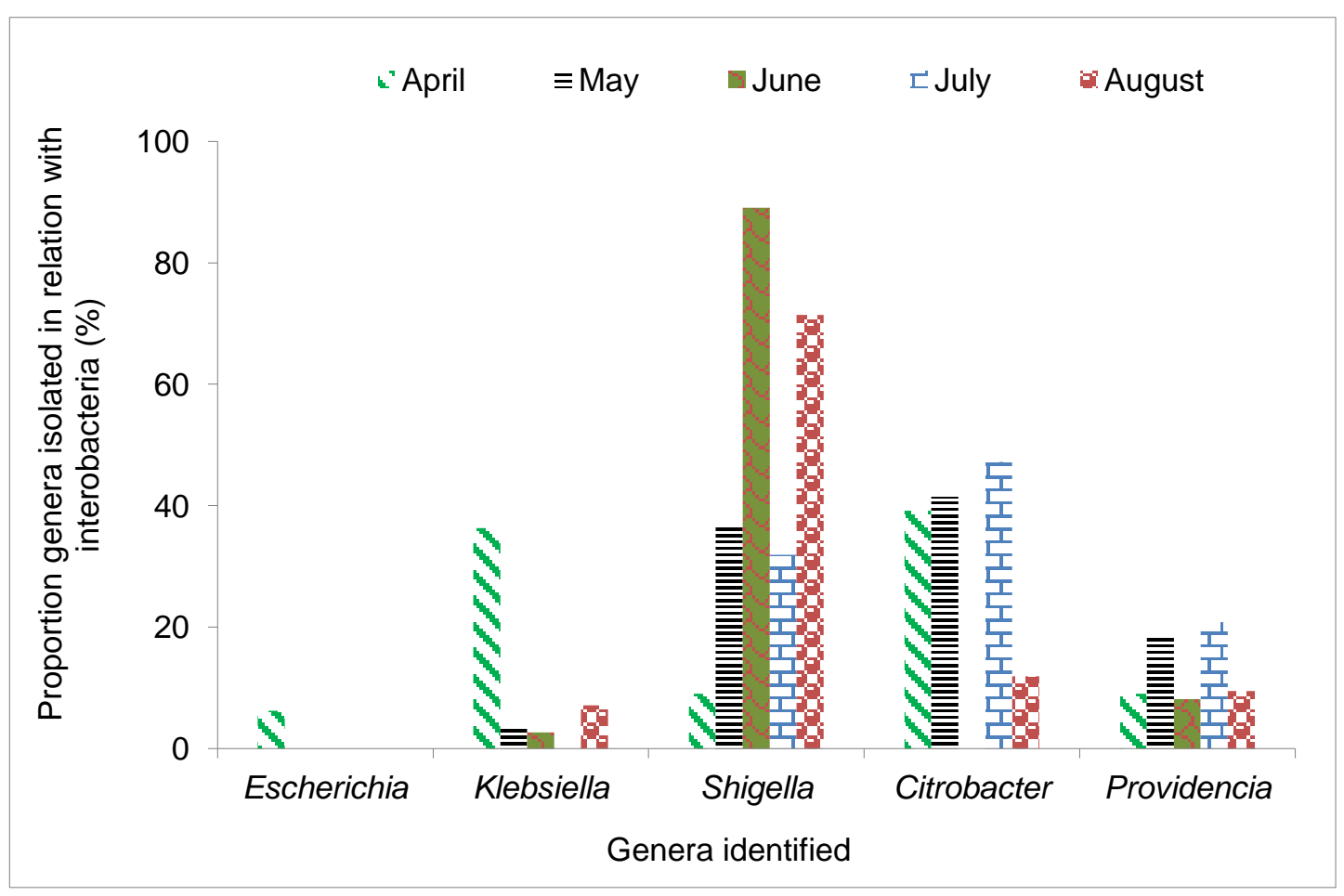

Fig. 2. Variations in the proportions of each bacterial genus identified compared to HAMBs 


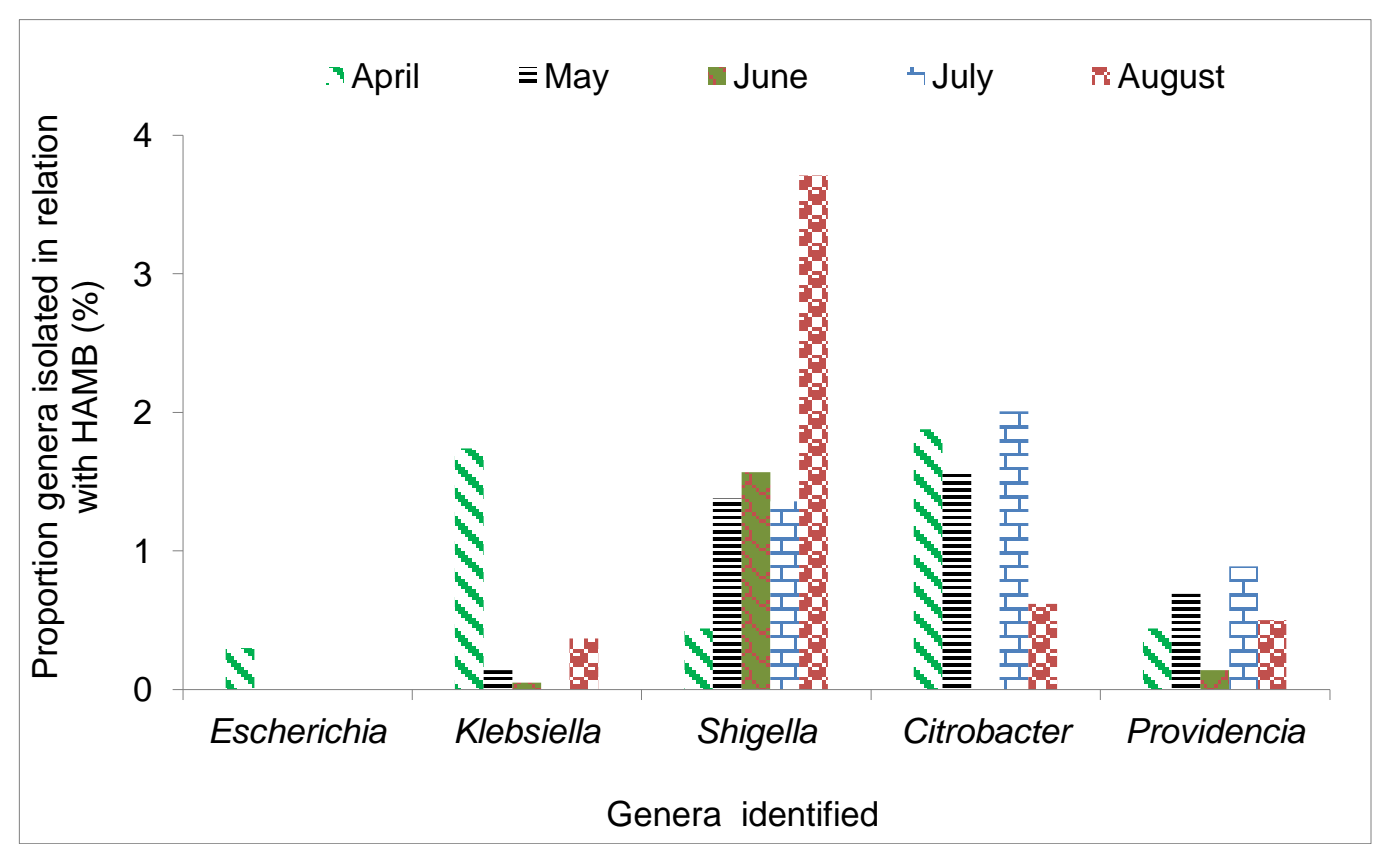

Fig. 3. Variations in the relative proportions of each identified bacterial genus compared to all Enterobacteria

Table 5. Correlations between the different bacterial strains isolated

\begin{tabular}{|c|c|c|c|c|c|c|}
\hline & Escherichia & Klebsiella & Shigella & Citrobacter & Providencia & HAMB \\
\hline Escherichia & 1 & $0.549^{\star *}$ & -0.335 & $0.512^{\star *}$ & -0.098 & 0.264 \\
\hline Klebsiella & & 1 & 0.06 & $0.397^{*}$ & -0.303 & 0.086 \\
\hline Shigella & & & 1 & 0 & 0.084 & 0.162 \\
\hline Citrobacter & & & & 1 & 0.173 & 0.147 \\
\hline $\begin{array}{l}\text { Providencia } \\
\text { HAMB }\end{array}$ & & & & & 1 & 0.316 \\
\hline
\end{tabular}

\subsection{Statistical Analysis}

\subsubsection{Spearman's correlation}

Spearman's " $r$ " correlation tests were carried out among the mean bacterial abundances of the various wells (Table 5) and between the bacterial mean abundances and physicochemical parameters (Table 6). The correlations made between the mean abundances of different isolated bacterial strains indicate a very significant and positive correlations between the abundances of the genera Escherichia and those of the genera Klebsiella (0.549) and Citrobacter (0.512). A significant and positive correlation was also noted between Citrobacter and Klebsiella (0.397) (Table 5).

From the correlations made between the physicochemical parameters and the mean abundances of isolated bacteria, it is seen that, very significant $(P<0.01)$ and positive correlations exist between the abundances of Klebsiella and parameters such as electrical conductivity (0.742), TDS (0.840), $\mathrm{NO}^{3-}(0.614)$ and $\mathrm{Mg}^{2+}(0.713), \mathrm{Ca}^{2+}(0.572)$ and $\mathrm{K}^{+}(0.589)$ (Table 6). The same observation was made between Escherichia and $\mathrm{Mg}^{2+}(0.549), \mathrm{Ca}^{2+}$ (0.565), $\mathrm{Na}^{+}(0.563)$ and $\mathrm{K}^{+}(0.565)$ and between Citrobacter and $\mathrm{K}^{+}$(0.549) (Table 6). Significant $(P<0.05)$ and positive correlations were recorded on the one hand between Escherichia and parameters such as $\mathrm{pH}(0.447)$, electrical conductivity (0.491), TDS (0.476) and $\mathrm{NO}^{3-}$ (0.487) and on the other hand between Citrobacter and $\mathrm{pH}(0.485)$ and $\mathrm{NO}^{3-}(0.397)$ (Table 6). A significant and negative correlation was noted between Citrobacter and oxidability (0.430) (Table 6).

The results of the correlations between biological and physicochemical variables show that 9 
variables significantly influenced the population and the distribution of bacteria throughout the study. Increase in $\mathrm{pH}$ of water significantly increases the abundance of bacteria of the genera Escherichia, Klebsiella and Citrobacter. This is in conformity with that of Nola et al. [35], where increase in $\mathrm{pH}$ sometimes favor the development of Pseudomonas aeruginosa, Aeromonas hydrophila, as well as the abundance of faecal coliforms and faecal streptococci. The levels of nitrates and oxidability, which represent the organic matter in the medium are significantly positively correlated with the genera Escherichia, Klebsiella and Citrobacter, for nitrates, and negatively with the genera Citrobacter, for oxidability. This difference in results imply the fact that, bacteria react differently with organic matter depending on the composition of the latter. Organic matter influences the availability of nutrients while serving at the same time as a source of energy and carbon for certain microorganisms [36]. Major cations $\left(\mathrm{Mg}^{2+}, \mathrm{Ca}^{2+}\right.$, $\mathrm{K}^{+}$and $\mathrm{Na}^{+}$ions) and other mineral elements represented by the electrical conductivity of water and TDS are very significantly correlated with bacteria of the genera Escherichia, Klebsiella and Citrobacter. Similarly, negative correlations between these cations $\left(\mathrm{Mg}^{2+}, \mathrm{Ca}^{2+}\right.$,
$\mathrm{K}^{+}$and $\mathrm{Na}^{+}$) and the other genera (Shigella and Providencia) are also noted. The influence of major cations on microflora of the soil and the subsoil varies depending on the ability of the bacterial species to degrade these cations (either to neutralize its toxicity or to make nutrients available) and the energy source which is necessary for their biosynthesis. In addition, the activities of certain microorganisms lead to the release and migration of certain ions such as $\mathrm{Mg}^{2+}, \mathrm{Ca}^{2+}, \mathrm{SO}_{4}{ }^{2-}$ and many others [24].

\subsubsection{Kruskal Wallis comparison}

Several comparison tests (Kruskal Wallis $\mathrm{H}$ test) between the mean abundances of HAMB and the different bacterial genera and between the abundances of bacterial and the months of sampling were carried out. The tests reveal that, a significant difference $(p<0.05)$ exists between the mean abundances of HAMB and those of Enterobacteriaceae (Table 7). The abundance of HAMB and those of bacteria of the genera Escherichia, Klebsiella and Citrobacter varied significantly $(p<0.05)$ between months of sampling. Only the abundances of bacteria of the genera Shigella remained constant over time (Table 8).

Table 6. Correlations between the bacteria isolated and the physicochemical parameters measured

\begin{tabular}{|c|c|c|c|c|c|c|}
\hline \multirow{2}{*}{$\begin{array}{l}\text { Physicochemical } \\
\text { variables }\end{array}$} & \multicolumn{6}{|c|}{ Microbiological variables } \\
\hline & HAMB & Escherichia & Klebsiella & Shigella & Citrobacter & Providencia \\
\hline Temperature & -0.033 & 0.094 & 0.124 & $\begin{array}{l}-0.163 \\
\end{array}$ & -0.045 & 0.294 \\
\hline $\mathrm{pH}$ & 0.222 & $0.447^{\star}$ & $0.424^{*}$ & -0.209 & $0.485^{\star}$ & 0.176 \\
\hline EC & 0.35 & $0.491^{*}$ & $0.742^{\star *}$ & -0.045 & 0.263 & -0.18 \\
\hline Color & -0.13 & -0.295 & 0.119 & 0.361 & -0.167 & 0.123 \\
\hline $\mathrm{O}_{2}$ & -0.034 & -0.132 & 0.05 & 0.32 & 0.23 & 0.14 \\
\hline $\mathrm{CO}_{2}$ & -0.031 & 0.392 & 0.212 & -0.14 & 0.29 & 0.164 \\
\hline TDS & 0.24 & $0.476^{*}$ & $0.840^{\star *}$ & 0.03 & 0.2 & -0.312 \\
\hline Nitrates & 0.256 & $0.487^{*}$ & $0.614^{\star *}$ & -0.041 & $0.397^{*}$ & -0.047 \\
\hline Oxidability & -0.094 & -0.137 & -0.259 & -0.144 & $-0.430^{*}$ & 0.113 \\
\hline $\mathrm{NH}_{4}^{+}$ & -0.129 & -0.123 & 0.255 & 0.319 & 0.135 & 0.143 \\
\hline Mg2+ & -0.079 & $0.549^{* *}$ & $0.713^{\star *}$ & -0.197 & 0.278 & -0.374 \\
\hline $\mathrm{Ca} 2+$ & 0.17 & $0.565^{\star *}$ & $0.572^{\star *}$ & 0.018 & 0.268 & -0.251 \\
\hline $\mathrm{Na}^{+}$ & 0.322 & $0.563^{\star *}$ & 0.267 & -0.373 & 0.052 & -0.064 \\
\hline $\mathrm{K}^{+}$ & 0.233 & $0.565^{\star *}$ & $0.589^{* \star}$ & -0.018 & $0.549^{* *}$ & -0.015 \\
\hline
\end{tabular}

Table 7. P-values indicating the significance thresholds relative to the comparison of the mean abundances of the genera of Enterobacteriaceae and of HAMB

\begin{tabular}{llllll}
\hline & \multicolumn{5}{c}{ Bacterial genera } \\
\cline { 2 - 6 } & Escherichia & Klebsiella & Shigella & Citrobacter & Providencia \\
\hline HAMB & $0.001^{*}$ & $0.001^{*}$ & $0.001^{*}$ & $0.001^{*}$ & $0.001^{*}$ \\
\hline
\end{tabular}


Table 8. P-values indicating the significance thresholds relating to the Kruskal-Wallis $\mathrm{H}$ test between the genera of Enterobacteriaceae and the months of sampling

\begin{tabular}{lllllll}
\hline & Escherichia & Klebsiella & Shigella & Citrobacter & Providencia & HAMB \\
\hline Month & $0.011^{*}$ & $0.003^{*}$ & 0.908 & $0.028^{*}$ & 0.544 & $0.024^{*}$ \\
\hline \multicolumn{5}{c}{} \\
& & ${ }^{*}: P<0.05$ & & &
\end{tabular}

\section{CONCLUSION}

Groundwater samples taken from certain wells in the Soa region of Cameroon in Africa were analyzed to deduce their bacteriological and physicochemical contents. Prior to that, the morphometric and hydrological characteristics of the sampling points were determined since they are known to influence the bacteriological and physicochemical characteristics of the water.

Piezometric and morphometric evaluation reveals that the groundwater of Soa especially that accessed through hand-dug wells has a low piezometric level and is not protected. This exposes the water to several sources of pollution.

Physicochemical assessment points to an acidic and poorly mineralized groundwater which is found susceptible to pollution and degradation of its physicochemical quality.

Bacteriological analysis reveals that the water in the study area is not recommended for drinking purpose because of the presence of pathogenic germs owing to the high levels of fecal pollution. These bacteria are responsible for gastroenteritis, hepatovesicular, vaginal and urinary tract infections in humans.

Physicochemical parameters such as $\mathrm{pH}$, electrical conductivity, TDS, oxidability, nitrates and major cations $\left(\mathrm{Ca}^{2+}, \mathrm{Na}^{+}, \mathrm{K}^{+}\right.$and $\mathrm{Mg}^{2+}$ ions $)$ are clearly seen to influence the load and distribution of bacteria in the water. The bacterial load is also influenced by the proximity of the wells to the sources of pollution and the level of maintenance of wells.

In general, this study can be considered as a baseline study that underscores the risk of groundwater pollution. It should therefore serve as a reference for future studies on the risk of pollution and contamination of groundwater in the Soa subdivision of Cameroon.

\section{DISCLAIMER}

The products used for this research are commonly and predominantly use products in our area of research and country. There is absolutely no conflict of interest between the authors and producers of the products because we do not intend to use these products as an avenue for any litigation but for the advancement of knowledge. Also, the research was not funded by the producing company rather it was funded by personal efforts of the authors.

\section{COMPETING INTERESTS}

Authors have declared that no competing interests exist.

\section{REFERENCES}

1. Heriarivony SC, Razanamparany B, Rakotomalala JE. Caractères physicochimiques et bactériologiques de l'eau de consommation (puits) de la commune rurale d'Antanifotsy, Region Vakinankaratra, Madagascar. Larhyss Journal. 2015;24: 7-17

2. Ndjama J, Mafany G, Biram E B, Mfopou Mewouo Y C, Tarkang C, Aboubakar A, Apohkeng Dongmo OL, Ekoa Bessa AZ. Evaluation of Surface Water Contamination Using Heavy Metal Pollution Indices in the Mgoua Watershed, Southwestern Cameroon. International Journal of Current Microbiology and Applied Sciences. 2021; 10 (11): 142-156.

3. Nkengfack $\mathrm{H}$, Edmond ND, François $\mathrm{K}$. Analyse des déterminants de l'offre de l'eau potable au Cameroun. HAL. 2017

4. Biguioh RM, Adogaye SBB, Pete PMN, Sobze MS, Kemogne JB, Colizzi, V. Microbiological quality of water sources in the West region of Cameroon: quantitative detection of total coliforms using Micro Biological Survey method. BMC public health. 2020; 20(1): 1-7.

5. Nola M, Ewoti OV, Nougang M, Moungang ML, Chihib N E, Krier F, Servais P, Hornez JP, Njine T. Involvement of cell shape and flagella the bacterial in retention during percolation of contaminated water through soil columns in tropical region. Journal of Environmental Science and health Part $A$. 2010; 45(11): 1297-1306. 
6. Payment $\mathrm{P}$, Locas $\mathrm{A}$. Pathogens in water: value and limits of correlation with microbial indicators. Ground Water. 2011; 49:4-11.

7. Upfold NS, Luke GA, Knox C. Occurrence of human enteric viruses in water sources and shellfish: A focus on Africa. Food and Environmental Virology. 2021;1-31.

8. Pial AC, Madjiki AG, Ndengue GD, Mbassi MFC. Disponibilité et qualité des eaux de boisson consommées dans quelques établissements scolaires de la ville de Yaoundé (Cameroun). Journal of Applied Biosciences. 2016;107: 10362-10370.

9. Nzeket $A B$, Moyo KB, Aboubakar $A$, Youdom YAS, Moussima YDA, Zing ZB, Sulem YNN, Mama A C, Mfopou M Y C. Assessment of Physicochemical and Heavy Metal Properties of Groundwater in Edéa (Cameroon). American Journal of Water Resources. 2019;7 (1): 1-10.

10. Moussima Yaka DA, Tiemeni AA, Zing ZB, Jokam NTLL, Aboubakar A, Nzeket A B, Fokouong T B H, Mfopou M Y C. Qualité physico-chimique et bactériologique des eaux souterraines et risques sanitaires dans quelques quartiers de Yaoundé VII, Cameroun. International Journal of Biological and Chemical Sciences. 2020; 14(5): 1902-1920.

11. Ngo BP, Nougang ME, Nana PA, Metsopkeng CS, Tamsa AA, Noah EOV, Moungang LM, Tamekou SL, Bayemi PH, Perrière $F$, Sime NT, Nola $M$. Relative importance of the bacteria Brucella, Salmonella, Staphylococcus and other indicator bacteria in some mountain farm waters in West-Cameroon (Central Africa) and the potential role of some environmental factors. World Journal of Advanced Research and Reviews. 2020; 08(02):081-094.

12. Nanga N, Ngene JP, Tsala DE, Ngoule C, Lamare N. Relation entre Pollution des Eaux de Sources, Forages et Maladies Hydriques Enregistrées au Centre Hospitalier Dominicain Saint Martin de Porres (CHDSMP) du Quartier Mvog-Betsi à Yaoundé. Health Sciences and Diseases. 2014;15 (3):1-8.

13. Lanjri AF, Brigui JA, Cadi E, Khaddor M, Salmoune F. Caractérisation physicochimique et bactériologique des eaux souterraines de Tanger (Physico-chemical and bacteriological characterization groundwater of Tangier). Journal of
Materials and Environment Science. 2014; 5: 2230- 2235.

14. Bivins A, Lowry S, Wankhede S, Hajare R, Murphy $\mathrm{H}$ M, Borchardt $M$, Brown J. Microbial water quality improvement associated with transitioning from intermittent to continuous water supply in Nagpur, India. Water Research. 2021; 117- 301.

15. Yin Z, Duan R, Li P, Li W. Water quality characteristics and health risk assessment of main water supply reservoirs in Taizhou City, East China. Human and Ecological risk assessment an International Journal. 2021; 27(8):2142-2160.

16. Kuete $M$, Dikoume A, Elong G. Aperçu historique et population actuelle. Commune rurale (édition), Soa Cameroun. 2004;48.

17. Letouzey R. Notice de la carte phytogéographique du Cameroun au 1/500.000 domaine sahérien et soudanais. Institut Carte International de Végétation, Toulouse. 1985; 142.

18. Vallerie M. Contribution à l'étude des sols du Centre- Sud Cameroun. Types de différenciation morphologique et pédologie sous climat sub-équatorial. Edition de L'ORSTOM, Paris. 1973;29:111.

19. Bilong P, Belinga S E, Volkoff B. Séquence d'évolution des paysages cuirasses et des sols ferrallitiques en zones forestières tropicales d'Afrique centrale. Place des sols à horizons d'argile tachetée. CR Academic Science, Paris. 1992;314(II) :109-115.

20. Rodier J, Legube B, Merlet $\mathrm{N}$, coll. L'analyse de l'eau. $9^{\mathrm{e}}$ édition, Dunod, Paris. 2009;1579.

21. Marchal N, Bourdon J L, Richard C. Les milieux de culture pour l'isolement et l'identification biochimique des bactéries. Dion-biologie appliquée, Paris. 1991; 505.

22. Asi $Q$ A, Ajeagah $G$ A. Biodiversity of microsporidian spores in groundwater of the Center Region of Cameroon: seasonality and relationship to ecological factors of the medium. International Journal of Environment and Science Technology (springer). 2020; 1-18.

23. Asi $Q$ A, Ajeagah $G$ A, Okoa $A T N$. Distribution of Cryptosporidium and Cyclospora in the soil around the wells and springs in Yaounde and environs: Role of some abiotic factors of the medium. Journal of Bio-science Research. 2020;6(6):41-49. 
24. Lasm T, Koffi Y T, Oga M S, Koffi K F, Jourda $\mathrm{P}$, Kanan K, Baka. Analysis of physico-chemical characteristics of Groundwater in Proterozoic Land Region of the Tiassale Area (Southern Cote d'ivoire). European Journal of Scientific Research. 2008; 3(20): 526-543.

25. Matini L, Mouton J M, Kongo-Mantono M S. Evaluation hydro-chimique des eaux souterraines en milieu urbain au SudOuest de Brazzaville, Congo. Afrique Science.2009; 05 (1):82-98.

26. Kouassi M A, Yao A K, Ahoussi E K, Seki C L, Yao A N, Kouassi I k, Biemi J. Apports des méthodes statistiques et hyrochimiques à la caractérisation des eaux des aquifères fissurés de la région du N'Zi-Comoé (centre-Est de la Cote d'Ivoire). Internationnal Journal of Biological and Chemical Sciences. 2010; 4(5).

27. Nganje TN, Hursthouse AS, Edet A, Stirling D, Adamu Cl. Hydrochemistry of surface water and groundwater in the shale bedrock, Cross River Basin and Niger Delta Region, Nigeria. Applied water Science. 2017;7(2):961 - 985.

28. Mbawala A, Abdou et Ngassoum M B. Evaluation de la pollution physico-chimique et microbienne des eaux de puits de DangNgaoundéré (Cameroun). International JournalBiological Chemical Sciences.2010; 4(6):1962-1975.

29. Lagnika M, Ibikounle M, Montcho JPC, Wotto VD, Sakiti NG. Caractéristiques physico-chimiques de l'eau des puits dans la commune de Pobè (Bénin, Afrique de l'Ouest). Journal of Applied Biosciences. 2014;79: 6887-6897.

30. Nougang ME, Djuikom E, Noah Ewoti OV, Moungang LM, Ateba Bessa $\mathrm{H}$. Abundance of Feacal ciliforms and Pathogenic E. coli in Groundwater in the Coastral Zone of Cameroon (Central
Africa) and Relationship with Some Abiotic Parameters. Current Research Journal of Biological Sciences. 2011;3(6):622-632.

31. WHO. Guidelines for drinking-water quality, third edition incorporating the first and second addenda, Recommendations. 2011;(1).

32. Mpakam HG, Kouam K, Jean-loup B, Ekodeck GE, Bernard D. Etude des facteurs de pollution des ressources en eau en milieu urbain : cas de Bafoussam (Ouest, Cameroun).

Available:https://www.google.fr/search/Mp akam/étude (download February $2^{\text {nd }}$ ). 2017.

33. Wright J, Gundry S, Conroy R. Household drinking water in developing countries: a systematic review of microbiological contamination between source and pointof-use. Tropical Medecine International Health. 2004;9:106-17.

34. Ndjama J, Kuitcha D, Awah T M, Beyala K $\mathrm{K}$ V, Nkamdjou S L, Ekodeck E G. Richesse spécifique et abondance bactérienne dans deux bassins versants (Mgoua et Bobongo) à Douala (Cameroun). Journal Africain des Science de l'environnement. 201;2 (12):71-83.

35. Nola M, Njiné T, Djuikom E, Sikati $F$. Faecal coliforms and faecal streptococci community in the underground water in an equatorial area in Cameroon (Central Africa): the importance of some environemental chemical factors. Water Research. 2002;36: 3289-3297.

36. Nola M, Njiné T, Boutin C, Messouli M, Servais P, Foto Menbohan S, Ngo Bidjeck L M, Zébazé Togouet H S, Kemka N. Retention of Escherichia coli from water infiltration in the equatorial soil in Cameroon (Central Africa): The role of various soil layers. Journal of Cameroon Academy of Sciences.2004;2: 107-116.

(0) 2021 Mafany et al.; This is an Open Access article distributed under the terms of the Creative Commons Attribution License (http://creativecommons.org/licenses/by/4.0), which permits unrestricted use, distribution, and reproduction in any medium, provided the original work is properly cited.

\section{Peer-review history:}

The peer review history for this paper can be accessed here: https://www.sdiarticle5.com/review-history/80919 